\title{
UPAYA KELEMBAGAAN DALAM PENGEMBANGANPARIWISATA PESISIR DAN PULAU-PULAU KECIL YANG BERKELANJUTAN DI KABUPATEN BIMA
}

\author{
Haeril', Nur Khusnul Hamidah $^{2}$, Mas'ud ${ }^{3}$, Nur Anilawati ${ }^{4}$ \\ Sekolah Tinggi Ilmu Sosial dan Ilmu Politik (STISIP) Mbojo,Indonesia \\ Email: haeril@ stisipbima.ac.id $^{1}$
}

\begin{abstract}
Abstrak
Tujuan penelitian ini untuk mengetahui bagaimana upaya kelembagaan dalam pengembanganPariwisata peisisir dan Pulau-pulau kecil yang berkelanjutan di Kabupaten Bima.Jenis penelitian yang dipakai dalam penelitian ini ialah deskriptif kualitatif. Subyek penelitian ini dipilih melalui teknik purposivesampling.Teknik pengumpulan data terdiri atas observasi, wawancara, dan dokumentasi. Sedangkan teknik analisa data dilakukan melalui model interaktif Miles dan Huberman yaitu; reduksi data, penyajian data, dan penarikan kesimpulan/verifikasi. Hasil penelitian menunjukkan bahwa dalam upaya kelembagaan untukpengembangan Pariwisata peisisir dan Pulau-pulau kecil yang berkelanjutan di Kabupaten Bima dilakukan melalui upaya membangun kemitraan dengan komunitas kecil di Daerah, namun belum mampu menghadirkan dan menarik minat para investor untuk berinvestasi dalam menopang kepariwisataan karena masalah keamanan investasi dan lemahnya kepastian hukum. Selain itu pengembangan pariwisata pesisir terhambat kepentingan dan ego sektoral, dimana Peruntukkan dan jenis pengembangan kawasan Pesisir dan Pulau-Pulau kecil di Kabupaten Bima yang tidak berdasarkan Perda Tata Ruang Wilayah Kabupaten Bima dan Perda rencana zonasi dan Pengelolaan Wilayah Pesisir Dan Pulau-Pulau Kecil, sehingga seringkali mengintervensi keberlanjutan kawasan-kawasan yang harusnya di kembangkan menjadi destinasi wisata.

Keywords: Kelembagaan, Pengembangan Pariwisata, Berkelanjutan, Pesisir Dan Pulau-Pulau Kecil.
\end{abstract}

\begin{abstract}
This research is to find out how institutional efforts in the development of coastal tourism and small islands are sustainable in Bima Regency. This type of research used in this research is descriptive qualitative. The subjects of this study were selected through a purposive sampling technique. Data collection techniques consist of observation, interviews, and documentation. While the data analysis technique is done through the interactive model of Miles and Huberman namely; data reduction, data presentation, and drawing conclusions / verification. The results showed that in the institutional effort for the development of coastal tourism and sustainable small islands in Bima Regency was done through efforts to build partnerships with small communities in the region, but have not been able to present and attract investors to invest in supporting tourism due to investment security issues and weak legal certainty. In addition, the development of coastal tourism is hampered by sectoral interests and egos, where the Designation and types of Coastal and Small Islands development in the Regency of Bima are not based on the Regional Regulation on Spatial Planning in the District of Bima and Regional Regulations on zoning and Management of Coastal Areas and Small Islands, so often intervening in the sustainability of areas that should be developed into tourist destinations.
\end{abstract}

Keywords: Institutional, tourism development, sustainable, Coastal zone and small islands. 


\section{INTRODUCTION}

Sebagai hasil kesepakatan komisi dunia tentang lingkungan dan pembangunan, maka telah diusung dua tema besar yakni ekonomi hijau dalam konteks pembangunan lestari dan penurunan angka kemiskinan, serta kerangka kelembagaan pembangunan berkelanjutan dalam agenda Sustainable Development Goals (SDGs) atau tujuan pembangunan berkelanjutan (Rahman, 2012). Pembangunan berkelanjutan merupakan cara untuk memenuhi kebutuhan saat ini tanpa mengorbankan kemampuan generasi mendatang, dengan terus berupaya untuk mencapai kemajuan sosial dan ekonomi dengan cara-cara yang tidak menguras sumber daya alam yang terbatas (Sahin \& Mete, 2016).

Wilayah pesisir dan pulau-pulau kecil merupakan bagian wilayah lautan Indonesia yang paling produktif (Soerjani, 2008: 22). Dahuri (2003: 12) menyebut sumberdaya pesisir dan pulau-pulau kecil di Indonesia dengan "Raksasa ekonomi yang masih tertidur" (the sleeping giant of economy), mengingat banyaknya potensi yang dimiliki namun belum dikelola dengan baik.Lebih khusus Rachmad (2012:70-71) menjelaskan bahwa potensi wilayah pesisir dan pulaupulau kecil Indonesia dipandang dari segi pembangunan adalah sebagai sumber daya yang dapat diperbaharui seperti perikanan, hutan mangrove, terumbu karang, padang lamun. Selain itu juga jasa-jasa lingkungan seperti; pariwisata berupa wisata bahari, perhubungan dan kepelabuhan serta penampung (penetralisasi) limbah".

Menurut Harahab (2010: 28-29) adanya kecenderungan sumberdaya daratan yang langka, maka target dasar pembangunan ekonomi Indonesia akan bertumpu pada zona pantai dan pulau-pulau kecil beserta sumber-sumbernya. Demikian yang disampaikan Ferrol, Dkk (2015), bahwa faktor sosial dan ekonomi merupakan daya tarik tersendiri yang mempengaruhi pembangunan pesisir.

Demikian di Kabupaten Bima. Berdasarkan aspek geografisnya, sebagian besar masyarakat Kabupaten Bima merupakan masyarakat yang tumbuh dan berkembang di wilayah pesisir(Biro ekonomi.ntbprov.go.id, 2013).

Menurut data Potensi Ekosistem, Energi dan Sumber daya mineral Laut, Pesisir dan Pulau-pulau kecil Kabupaten Bima tahun 2016, bahwa Kabupaten Bima memiliki 155 pulau kecil, 74 diantaranya sudah memiliki nama, sedangkan tiga diantaranya memiliki populasi penduduk yang padat, dengan sumber daya alam yang potensial untuk pengembangan Pariwisata seperti Pulau Ular, Pulau Kelapa, Bajo Pulo, Pulau Sobu, Pulau Wadumbolo dan lainnya. Namun, mengingat infrastruktur pendukung masih relatif terbatas, akses jalan yang rusak membuat pengembangan wisata menjadi sangat terhambat.

Selain itu juga terdapat 550,8 hektar luasan Hutan Mangrove yang potensial untuk pengembangan ekowisata, tersebar di seluruh wilayah pesisir Kabupaten Bima. Di antaranya masih dalam kondisi baik dengan luas kawasan sebanyak 158,79 hektar, kemudian dalam kondisi sedang dengan luas kawasan 125,07 hektar,sedangkan dalam kondisi rusak dengan luas kawasan 266,95 hektar.

Sehingga untuk mendukung pengembangan Pariwisata sekaligus untuk mengurangi potensi kerusakan sumber daya pesisir dan pulau-pulau kecil di Kabupaten Bima, maka penting untuk mendorong political will (kemauan politik) Pemerintah dan masyarakat untuk turut berpartisipasi dalam bertindak. Tindakan yang dimaksud ialah upaya pengembangan dan pengimplementasian kolaborasi secara kelembagaan di antara pemangku kepentingan dalam aktivitas program 
konservasi, untuk mewujudkan pembangunan berkelanjutan, efektivitas pengelolaan kawasan,serta peningkatan program pemberdayaan sosial-ekonomi masyarakat lokal melalui pengembangan Pariwisata.Untuk itu dilakukan penelitian yang bertujuan mengetahui bagaimana upaya kelembagaan dalam pengembanganPariwisata peisisir dan Pulaupulau kecil yang berkelanjutan di Kabupaten Bima.

\section{METODOLOGI}

Penelitian ini menggunakan metode deskriptif kualitatif. Pendekatan kualitatif ini dipilih dalam penelitian ini guna melihat esensi penelitian sehingga hasil yang diperoleh rinci dan detail.

Subyek penelitian ini dipilih melalui teknik purposivesampling dengan mempertimbangkan aspek keahlian dan pemahaman responden mengenai pengembangan pariwisata pesisir dan pulaupulau keci di Kabupaten Bima, antaralain, Kepala Dinas Pariwisata, Dinas Lingkungan Hidup, Dinas Kelautan dan Perikanan, Kelompok Sadar Wisata (Pokdarwis) Kecamatan Sape, Kecamatan Bolo, Kecamatan Lambu, Kecamatan Langgudu, dan Kecamatan Wera, dan LSM maupun Komunitas penggiat lingkungan.

Teknik pengumpulan data terdiri atas observasi (observation), wawancara (interview), dan dokumentasi (documentation). Sedangkan teknik analisa data dilakukan melalui model interaktif Miles dan Huberman yaitu; reduksi data; penyajian data; dan penarikan kesimpulan/verifikasi.

\section{RESULT AND DISCUSSION}

Kelembagaan dianggap sebagai penyebab segala perubahan pembangunan. Membangun kelembagaan sebagai upaya untuk membangun organisasi mencari dukungan-dukungan yang memungkinkan untuk melakukan inovasi-inovasi seperti kemitraan dan jaringan dalam lingkungan organisasi (Ife dan Tesorioro, 2014:110).

\section{Membangun Kemitraan}

Peran kelembagaan formal maupun informal sangat berpengaruh terhadap pembangunan. Kedua lembaga ini selalu mempengaruhi berbagai kegiatan sosial ekonomi masyarakat, dan sering dijadikan sebagai pilihan dalam upaya memperbaiki dan meningkatkan pendapatan masyarakat. Oleh karena demikian apabila partisipasi masyarakat sangat dibutuhkan dalam proses pembangunan, maka penguatan kelembagaan sosial dan ekonomi masyarakat merupakan suatu syarat pokok.

Lembaga yang dimaksud adalah lembaga yang berkompeten, baik secara langsung maupun tidak langsung, ataupun jejaring pemangku kepentingan yang berkaitan dengan pengembangan Pariwisata Pesisir dan Pulau-pulau kecil di Kabupaten Bima.

Hasil temuan menunjukkan bahwa kemitraan dari sisi pengelolaan Pariwisata di Wilayah Pesisir dan Pulau-pulau kecil Kabupaten Bima terutama untuk pengembangan, penataan, pemeliharaan dan promosi wisata, Pemerintahsudah berupaya menempatkan masyarakat tidak hanya sebagai objek kebijakan, namun juga sebagai subjek dari kebijakan pemerintah untuk diberdayakan dalam pengelolaan pariwisata. Terbukti dengan dibentuknya Pokdarwis, komunitas Pesisir dan Kelompok Ekonomi Kreatif (Ekraf) sebagai kelompok atau komunitas mitra Pemerintah dalam menjalankan sapta pesona dan penggerak wisata pesisir dan pulau-pulau kecil di Kabupaten Bima.

Dinas Pariwisata sudah mampu memberdayakan Kelompok Sadar Wisata (Pokdarwis) dari masing-masing Kecamatan yang mempunyai potensi wisata. Selain itu 
Sadar Wisata: Jurnal Pariwisata

(p-ISSN 1858-0112, e-ISSN 15537-37677)

kehadiran Pokdarwis juga untuk mendukung program prioritas Pemerintah Daerah Kabupaten Bima dalam pengembangan wisata di kawasan Sangiang, Komodo, dan Sape (SAKOSA), walaupun saat ini juga masih mendapat berbagai macam tanggapan dari masyarakat terkait pemberian nama SAKOSA yang dinilai tidak representatif dari potensi kawasan pesisir dan pulau-pulau kecil yang ada di Kabupaten Bima.

Selain Kelompok Sadar Wisata (Pokdarwis), Dinas Pariwisata juga bekerjasama dengan komunitas Balumba untuk promosi wisata dan kebudayaan diwilayah pesisir kecamatan Sape, Komunitas masyarakat peduli wisata dan Ekonomi Kreatif (Ekraf) wilayah Pesisir Kecamatan Wera, dan Komunitas Lariti untuk ruang lingkup wisata pantai Lariti Kecamatan Lambu. Berikut beberapa kawasan wisata pesisir dan pulau-pulau kecil yang sedang dikembangkan selain yang telah disebutkan diatas antaralain; Pantai Toro Wamba, Pantai Mata Mboko, Kawasan budidaya Sarang Burung Walet Bajo Pulau dan Pulau Kelapa (Kecamatan Sape), Pantai Papa dan Budidaya Mutiara (Kecamatan Lambu), Pulau Ular, Pulau Sangiang dan Karombo Wera (Kecamatan Wera), Pantai Nisa Bea Teluk Waworada Kecamatan Langgudu, Pantai Wane Soranadi Kecamatan Monta, serta Pantai Kalaki kecamatan Palibelo.

Namun disisi lain, sebagai spektrum fundamental untuk pembangunan Daerah maka untuk mengembangkan pariwisata tidak cukup hanya bermitra kerja dengan komunitas kecil di Daerah. Kehadiran para investor menjadi penting untuk menopang kepariwisataan terutama dengan terbatasnya infrastruktur penunjang dan fasilitas pelayanan wisata, akibat minimnya anggaran Daerah (APBD) Kabupaten Bima. Namun karena belum terbentuknya citra Daerah sebagai tujuan destinasi pariwisata,
Volume 3 No. 1 Juni Tahun 2020

http://jurnal.unmuhjember.ac.id/index.php/wisata

juga tidak dapat dipungkiri pula rentannya keamanan serta kepastian hukum untuk investor dengan melekatnya identitas sebagai Daerah rawan konflik yang berpengaruh terhadap minat para investor asing maupun lokal untuk berinvestasi di Kabupaten Bima.

Karena investor pada umumnya mengingingkan kepastian hukum dan keamanan dalam berinvestasi. Seperti halnya yang pernah terjadi dipantai Wane, dimana masyarakat yang terus melakukan demo kepada pemerintah dan investor untuk memberhentikan kegiatan pembangunan fasilitas penginapan di pinggir pantai, hingga akhirnya menyebabkan investor menarik minat investasi pada pengembangan pantai tersebut.

Selain itu berdasarkan temuan, bahwa para investor lebih memilih kawasankawasan yang telah memiliki sarana penunjang, terutama sarana yang mampu menarik pasar untuk berkunjung. Karena kebanyakan investor kepariwisataan yang masih menjunjung budaya "instant" dimana mereka lebih menyukai melakukan investasi pada pariwisata yang dapat segera memberikan keuntungan.

\section{Upaya Pengembangan Pariwisata yang Berkelanjutan}

Pada dasarnya Keraf (2010:192) menjelaskan bahwa konsepkeberkelanjutan tidak lain adalah sebagai upaya untuk mensikronkan, mensinergikan, dan memberi bobot yang sama bagi tiga aspek pembangunan, yaitu aspek ekonomi, aspek sosial-budaya, dan aspek lingkungan hidup.

Sehingga pada bagian ini menyoroti pelaksanaan pembangunan berkelanjutan di Kabupaten Bima dalam konteks pegelolaan pariwisata di wilayah pesisir dan pulaupulau kecil dalam rangka pembangunan ekonomi, pembangunan sosial, dan perlindungan lingkungannya. 
Sadar Wisata: Jurnal Pariwisata

(p-ISSN 1858-0112, e-ISSN 15537-37677)

Untuk mengukur pembangunan sosial ekonomi masyarakat dapat dilihat dari adanya redistribusi pendapatan dan kesejahteraan. Banyaknya infrastruktur jalan yang rusak di wilayah pesisir bukan saja menyebabkan aksesibilitas begitu sulit juga berdampak pada pembangunan pariwisata wilayah pesisir dan pulau-pulau kecil di Kabupaten Bima, dimana menjadi sangat terhambat. Padahal jumlah wisatawan mancanegara yang datang ke Kabupaten Bima sudah sangat meningkat. Dimana pada tahun 2017 berdasarkan data dari Dinas Pariwisata Kabupaten Bima terdapat 4.758 pengunjung pariwisata di wilayah pesisir dan pulau-pulau kecil yang pada tahuntahun sebelumnya sepi dari kunjungan wisatawan mancanegara. Sehingga untuk merespon itu maka penyediaan infrastruktur, fasilitas dan pelayanan pariwisata serta aksesibilitas menjadi sangat penting untuk dilakukan. Saat ini akomodasi penginapan untuk wisatawan domestik maupun mancanegara di kawasan wisata kecamatan pesisir sudah ada peningkatan. Penyediaan fasilitas ini sebagai langkah untuk menunjang pendapatan ekonomi masyarakat pesisir.

Namun demikian, di Kabupaten Bima terdapat 64 Desa pesisir dengan sebanyak 14.201 orang yang tercatat berprofesi sebagai nelayan,memiliki 1.203 jumlah perahu biasa, kemudian sebanyak 1.317 unit perahu motor, dan 1.907 unit Kapal Motor, namun masih tingginya jumlah rumah tangga pra sejahtera diwilayah pesisir sebagai bukti kelemahan dalam pemberdayaan sosial dan ekonomi masyarakat pesisir di Kabupaten Bima. Berikut data klasifikasi kesejahteraan masyarkat pesisir di Kabupaten Bima :

Tabel 1. Klasifikasi Kesejahteran masyarakat pesisir berdasarkan Kecamatan di Kabupaten Bima
Volume 3 No. 1 Juni Tahun 2020

http://jurnal.unmuhjember.ac.id/index.php/wisata

\begin{tabular}{|c|c|c|c|}
\hline \multirow[t]{2}{*}{ Kecamatandsushidissict } & \multicolumn{2}{|c|}{ Keluarga Pra-sejalitera (Iahun) } & \multirow{2}{*}{$\begin{array}{c}\text { Keluarga Sejaltern } \\
\text { (2017) }\end{array}$} \\
\hline & 2014 & 2017 & \\
\hline Sape & 271 & 1841 & 2820 \\
\hline Langyudu & 15.48 & 1834 & 689 \\
\hline Lambu & 693 & 1195 & 1731 \\
\hline Nera & 2806 & 1126 & 1438 \\
\hline Pallibeo & 156! & 2158 & 1036 \\
\hline Bolo & 1521 & 1879 & 2870 \\
\hline Soromandi & 1777 & 415 & 1123 \\
\hline Sangagr & 3567 & 718 & 728 \\
\hline Iotal & 13744 & 11166 & 11107 \\
\hline
\end{tabular}

Sumber: diolah dari data BPS Kabupaten Bima dalam angka (2018).

Kondisi diatas menunjukkan bahwa program-program pemberdayaan sosialekonomi secara kelembagaan termasuk melalui upaya pemanfaatan pariwisata yang dilakukan oleh stakeholder selama ini belum menunjukkan dampak signifikan terhadap peningkatan sosial-ekonomi masyarakat pesisir.

Sedangkan dari aspek lingkungannya, berdasarkan temuanbahwa kawasan yang peruntukkannya untuk pengembangan destinasi wisata pantai, namun juga mendapatkan izin untuk pengembangan budidaya perikanan di kawasan tersebut, seperti pantai Torowamba dan Mata Mboko Kecamatan Sape, ditambah lagi dengan aktivitas penambangan pasir secara illegal yang menyebabkan kondisi pantai tersebut rusak parah. Demikian juga wisata Pantai Kalaki Kecamatan Palibelo, yang semulanya oleh Dinas Pariwisata Kabupaten Bima telah mengembangkan wahana "water boom" dan Snorkling untuk mendukung destinasi wisata pantai tersebut, namun telah dialihkan fungsinya untuk proyek pengembangan jalan dua arah. 
Sadar Wisata: Jurnal Pariwisata

(p-ISSN 1858-0112, e-ISSN 15537-37677)

Selain itu, juga kawasan peruntukkan untuk konservasi dan pengembangan Pariwisata berdasarkan Perda Nomor 9 tahun 2011 tentang Tata Ruang Wilayah Kabupaten Bima yang juga didukung Peraturan Daerah Kabupaten Bima Nomor 2 Tahun 2013 tentang rencana zonasi Dan Pengelolaan Wilayah Pesisir Dan PulauPulau Kecil seperti di Teluk Waworada dan Rompo Kecamatan Langgudu, Teluk Sape, Desa pesisir Bajo Kecamatan Soromandi, Desa Daru Kecamatan Belo, Desa Soro dan Lambu Kecamatan Lambu, juga Desa Sondo Kecamatan Monta yang telah banyak di kapling oleh pengusaha yang sebagian dijadikan tambak budidaya perikanan dalam skala besar, bahkan banyak yang tidak mengantongi Surat Izin Usaha Perikanan (SIUP) dari instansi terkait, maupun Analisis Dampak Lingkungan (AMDAL).

Demikianupaya Pemerintah untuk mengembangkan mangrove sebagai pertahahanan di wilayah pesisir juga sekaligus sebagai sumber daya potensial pengembangan ekowisata, justru keberadaannya sedang terancam oleh kerusakan akibat penggunaan kayu mangrove untuk kebutuhan memasak dan ekstensifikasi lahan tambak, serta pemukiman warga.Selain itu juga akibatrencanan Pemerintah melalui Dinas Pekerjaan Umum membangun dan memperpanjang 'runway" Bandara Sultan Muhammad Salahuddin Kabupaten Bima, padahal tepat disekitar Bandara tersebut terdapat puluhan hektar kawasan mangrove alam yang sudah dikembangkan menjadi destinasi wisata diwilayah tersebut.

Untuk itu Pemerintah harus meperjelas dokumen perencanaan tentang peruntukkan dan jenis pengembangan (zonasi) pada kawasan pesisir dan pulau-pulau kecil di Kabupaten Bima. Karena sebagian besar pengembangan di pesisir Kabupaten Bima tidak berdasarkan dokumen perencanaan
Volume 3 No. 1 Juni Tahun 2020

http://jurnal.unmuhjember.ac.id/index.php/wisata

yang jelas, sehingga seringkali ada "perang" kepentingan atau ego sektoral, dimana upaya pengembangan potensi pariwisata yang diharapkan mampu menopang perekonomian masyarakat pesisir selalu mendapat intervensi.

\section{KESIMPULAN}

Adapun kesimpulan dalam penelitian ini adalah sebagai berikut:

1. Upaya kelembagaan dalam pengembangan Pariwisata peisisir dan Pulau-pulau kecil yang berkelanjutan di Kabupaten Bima dilakukan melalui upaya membangun kemitraan dengan komunitas kecil di Daerah seperti Pokdarwis, komunitas Pesisir dan Kelompok Ekonomi Kreatif (Ekraf), serta dengan komunitas Balumba, namun belum mampu menghadirkan dan menarik minat para investor untuk berinvestasi dalam menopang kepariwisataan karena masalah keamanan dan lemahnya kepastian hukum, ditambah dengan identitas Kabupaten Bima sebagai Daerah rawan konflik.

2. Peruntukkan dan jenis pengembangan kawasan Pesisir dan Pulau-Pulau kecil di Kabupaten Bima yang tidak berdasarkan Perda Tata Ruang Wilayah Kabupaten Bima dan Perda rencana zonasi Dan Pengelolaan Wilayah Pesisir Dan PulauPulau Kecil. Sebagian besar pengembangan di pesisir Kabupaten Bima tidak berdasarkan dokumen perencanaan yang jelas, sehingga seringkali mengintervensi keberlanjutan kawasan-kawasan yang harusnya di kembangkan menjadi destinasi wisata. 
Sadar Wisata: Jurnal Pariwisata

(p-ISSN 1858-0112, e-ISSN 15537-37677)

\section{DAFTAR PUSTAKA}

Creswell, J. W., \& Clark, V. L. P. (2007). Designing and conducting mixed methods research.

Dahuri, Rokhmin. 2003. Keanekaragaman Hayati Laut "Aset Pembangunan Berkelanjutan Indonesia”. Gramedia Pustaka Utama. Jakarta.,

Dahuri, R. (2003). Paradigma baru pembangunan Indonesia berbasis kelautan.

Ferrol-Schulte, Dkk, (2015). Coastal livelihood vulnerability to marine resource degradation: A review of the Indonesian national coastal and marine policy framework. Marine Policy, 52, 163-171.

Harahab, Nuddin. 2010. Penilaian Ekonomi Ekosistem Hutan Mangrove dan Aplikasinya dalam Perencanaan Wilayah pesisir. Yogyakarta. Graha Ilmu. Cetakan Pertama.

Ife, Jim dan Tesorioro, Frank. 2014. Community Development "alternativePengembangan masyarakat di era globalisasi. Pustaka Pelajar. Yogyakarta.

Keraf, Sony A. 2010. Etika Lingkungan Hidup. Kompas. Jakarta.

Rachmad K.. 2012. Sosiologi lingkungan dan sumber daya Alam. AR-RUZZ Media. Jogjakarta. Cetakan ke I.

Rahman, A. B. (2012). MDG ver 2.0: menuju sustainable development goals (sdgs) di indonesia.

Sahin, S., \& Mete, J. (2016). Sustainable Development: Environmental, Economical, Social Well-Being for Today and Tomorrow. Mimbar Pendidikan, 1(1).

Soerjani, Mohamad et. Al. 2008. Lingkungan : Sumberdaya Alam dan Kependudukan Dalam Pembangunan. Universitas Indonesia Press. Jakarta.
Volume 3 No. 1 Juni Tahun 2020

http://jurnal.unmuhjember.ac.id/index.php/wisata

Peraturan Daerah Nomor 9 Tahun 2011 Tentang Rencana Tata Ruang Wilayah Kabupaten Bima 2011-2031 BPS Kabupaten Bima dalam angka (2018) 